\title{
Effect of potash application on growth, yield and yield components of spring maize hybrids
}

\author{
Asad Ali Khan*1, Mohammad Nauman Khan ${ }^{1}$, Inamuallah ${ }^{1}$, Shahen Shah ${ }^{1}$, \\ Inayat Ur Rahman Arshad ${ }^{2}$, Ihsan Muhammad ${ }^{2}$, Amir Zeb $^{3}$ and Imran ${ }^{1}$ \\ ${ }^{1}$ Department of Agronomy, The University of Agriculture, KPK, Peshawar, Pakistan \\ ${ }^{2}$ Department of Soil and Environmental Sciences, The University of Agriculture, KPK, Peshawar, Pakistan \\ ${ }^{3}$ Department of Horticulture, The University of Agriculture,KPK, Peshawar, Pakistan \\ *Corresponding author email: sami435889@yahoo.com
}

\section{Citation}

Asad Ali Khan, Mohammad Nauman Khan, Inamuallah, Shahen Shah, Inayat Ur Rahman Arshad, Ihsan Muhammad Amir Zeb, and Imran. Effect of potash application on growth, yield and yield components of spring maize hybrids. Pure and Applied Biology Vol. 4, Issue 2, 2015, pp 195-203.

\section{Abstract}

Productivity of spring maize hybrids was compared under different levels of potash at Agronomy Research Farm, The University of Agriculture KPK Peshawar during spring, 2014. The experiment was carried out in randomized complete block design (RCBD) with four replications. Four levels of $\mathrm{K}_{2} \mathrm{O} @ 0,60,90$ and $120 \mathrm{~kg} \mathrm{ha}^{-1}$, and four spring maize hybrids viz., 30K08, 2031, CS200 and 3025 were studied. The texture of the experimental area soil was silty clay loam with alkaline nature ( $\mathrm{pH} 7.5-7.8)$. The soil was deficient in total $\mathrm{N}\left(\leq 0.53 \mathrm{~g} \mathrm{~kg}^{-1}\right.$ soil) and K $\left(\leq 92 \mathrm{mg} \mathrm{kg}^{-1}\right)$ soil. A uniform dose of $150 \mathrm{~kg} \mathrm{~N} \mathrm{ha}^{-1}$ and $90 \mathrm{~kg} \mathrm{P} \mathrm{ha}^{-1}$ in the form of urea and DAP was applied. Nitrogen was applied in two equal splits i.e. $50 \%$ at sowing and $50 \%$ at $2^{\text {nd }}$ irrigation. Sulphate of potash was used as a source of potash. All K and P dose was applied at sowing time. Results exhibited that there was a considerable effect of $\mathrm{K}_{2} \mathrm{O}$ levels on plant height, leaf area and yield and yield components except number of ears plant ${ }^{-1}$ and plants at harvest. Applying $\mathrm{K}_{2} \mathrm{O}$ at the level of $90 \mathrm{~kg} \mathrm{ha}^{-1}$ boosted yield and yield components yet increasing level of $\mathrm{K}_{2} \mathrm{O}$ above $9090 \mathrm{~kg}$ $\mathrm{ha}^{-1}$ had no profound effect. Among the hybrids, CS200 performed better by producing more grain and biological yield. Hence for obtaining higher grain yield, Hybrid-CS200 with application of $\mathrm{K}_{2} \mathrm{O}$ at the rate of @ $90 \mathrm{~kg} \mathrm{ha}^{-1}$ is recommended.

Keyword: Potash levels; spring maize hybrids; yield and yield components

\section{Introduction}

In plant growth and sustainable crop production potassium $(\mathrm{K})$ as a macronutrient plays a vital role [1]. It assists in opening and closing of stomata, osmoregulation of plant cell [2], and maintains turgor pressure of cell which is necessary for cell expansion. It is well known for the triggering of more than 60 enzymes. Application of $\mathrm{K}$ potassium has primitive influence on development and growth [3] and grain yield in maize [4]. It not only affects the rate of 
photosynthesis but also regulates transport of assimilates in maize. It is familiar for its interaction both synergistic and antagonistic with essential micro and macro nutrients. Potassium $\mathrm{K}$ application is known vital for effective nitrogen utilization and have a fairly consistent result on lowering tissue concentration of $\mathrm{Ca}^{2+}$ and $\mathrm{Mg}^{2+}[5,6]$. Due to modification in uptake, accumulation, translocation, growth and utilization $[7,8]$ The maize genotypes respond to potassium $\mathrm{K}$ application in a different way. $\mathrm{K}$ responsive genotype is a complex one, involving a mixture of uptake and utilization efficiency mechanisms. Cultivars effective in $\mathrm{K}$ uptake and its utilization may have a larger leaf area. Improved translocation of $\mathrm{K}$ into plant organs, enhanced ability to uphold cytosolic $\mathrm{K}^{+}$concentration within optimal ranges and augmented capacity to substitute $\mathrm{Na}^{+}$for $\mathrm{K}^{+}$are the key mechanisms underlying $\mathrm{K}$ utilization efficiency. Hybrids with low harvest index under meager $\mathrm{K}$ supply were K-inefficient. Ability to bear low concentrations of potassium $\mathrm{K}$ in shoot tissue where $\mathrm{K}$ supply was rare, was also important in determining $\mathrm{K}$ proficiency for grain yield. Hybrids which are K-efficient may have the potential to improve the sustainability and efficiency of cereal cropping systems. Proficient plant varieties could have improved fertilizer use efficiency (FUE) [9] and leave low soil nitrogen and K as it is now understood that both of these elements should be present in adequate and balanced amounts for appropriate crop growth [1] and hence may conserve environment and decrease input cost and. Potassium $\mathrm{K}$ in the soils is declining rapidly and net $\mathrm{K}$ draining rate is even steeper $(0.3$ $\mathrm{kg} \mathrm{ha}^{-1}$ year $^{-1}$ ) in Pakistan. It may be due to the inappropriate utilization of $\mathrm{K}$ in Pakistan in comparison to the world average $\mathrm{K}$ use. Consequently, it was needed to recognize spring maize hybrids effective in $\mathrm{K}$ uptake to provide best opportunities for future breeding research towards low input, sustainable and environment friendly agriculture. Therefore, the present study was mainly aimed to explore at exploiting the genetic variation among four different spring maize hybrids for their suitable $\mathrm{K}$ level.

\section{Materials and Methods Experimental site}

The experimental site was located at $34^{0} 01^{\prime \prime}$ $\mathrm{N}$ latitude and 71035" E longitude with altitude of $359 \mathrm{~m}$ (1178 ft) above sea level. The environmental conditions of research farm were warm to hot and semi-arid subtropical continental climate. The soil was well develop, deep silty clay loam. The nature of soil was alkaline with $\mathrm{pH}$ 7.5-7.8. The soil was deficient in total $\mathrm{N}(\leq 0.53 \mathrm{~g}$ $\mathrm{kg}^{-1}$ soil $)$ and $\mathrm{K}\left(\leq 92 \mathrm{mg} \mathrm{kg}^{-1}\right)$ soil.

\section{Experimental details}

An experiment entitled "effect of various $\mathrm{K}$ levels on spring maize hybrids" was conducted during spring, 2014 at Agronomy Research Farm, The University of Agriculture KPK, Peshawar. The experiment was consisting of two factors i.e. potash levels and maize hybrids. A randomized complete block design (RCBD) was used. Plot size was kept $3.5 \mathrm{~m}$ by $3 \mathrm{~m}$ with row to row and plant to plant distance of $70 \mathrm{~cm}$ and 25 respectively, having 5 rows. A uniform dose of $150 \mathrm{~kg} \mathrm{~N} \mathrm{ha}^{-1}$ and $90 \mathrm{~kg} \mathrm{P} \mathrm{ha}^{-1}$ in the form of urea and DAP was applied. Nitrogen was applied in two equal splits i.e. $50 \%$ at sowing and $50 \%$ at $2^{\text {nd }}$ irrigation. Sulphate of potash was used as a source of potash. All K and $\mathrm{P}$ dose was applied at sowing time. All other cultural practices were carried out uniformly for all the experimental units. Presoil analysis was carried out for $\mathrm{K}, \mathrm{N}$ and $\mathrm{pH}$. The texture of the experimental area soil was silty clay loam with alkaline nature $(\mathrm{pH}$ 7.5-7.8). The soil was deficient in total $\mathrm{N}(\leq$ $0.53 \mathrm{~g} \mathrm{~kg}^{-1}$ soil $)$ and $\mathrm{K}\left(\leq 92 \mathrm{mg} \mathrm{kg}^{-1}\right)$ soil.

Following parameters were suited during the experiment: 
Leaf area plant ${ }^{-1}\left(\mathrm{~cm}^{2}\right)$

Leaf area was taken manually of three plants in each plot at silking stage by using the following formulae:

L.A. = Leaf length $(\mathrm{cm}) \times$ Leaf width $(\mathrm{cm}) \times$ 0.75 .

\section{Plant height (cm)}

Plant height was recorded by recording the plant height of five plants from ground level to tip of each plot with the help of meter rod.

Number of plants at harvest $\left(\mathrm{ha}^{-1}\right)$

Plants in every plot were recorded and then converted to ha ${ }^{-1}$ in order.

Number of ears plant $\mathbf{t}^{-1}$

Randomly ten plants in each plot were selected; their ears were counted and averaged to record number of ears plant ${ }^{-1}$.

\section{Number of grains ear ${ }^{-1}$}

The ears harvested for grains yield were used for the determination of number of grains per ear by selecting five ears randomly from each plot, dried and shelled for counting the grain ear ${ }^{-1}$.

\section{Thousand grains weight (g)}

Data regarding 1000 grains weight was recorded by counting randomly selected grains from seed plot.

Grain yield (kg ha-1)

Grain yield was recorded after shelling of ears from each three rows and was converted into $\mathrm{kg} \mathrm{ha}^{-1}$.

\section{Biological yield $\left(\mathrm{kg} \mathrm{ha}^{-1}\right)$}

Biological yield was recorded by weighing all the plants harvested from three rows and then converted into $\mathrm{kg} \mathrm{ha}^{-1}$.

\section{Statistical analysis}

The data obtained was subjected to analysis of variance techniques appropriate for randomized complete block design and means of the treatments were compared using least significant difference (LSD) [9].

\section{Results}

\section{Leaf area plant ${ }^{-1}\left(\mathrm{~cm}^{2}\right)$}

Leaf area was significantly affected by potash $(\mathrm{K})$ application and hybrids $(\mathrm{H})$ and their interaction $(\mathrm{K} \times \mathrm{H})$ (Table 1). Potash applied@120 kg ha ${ }^{-1}$ had the largest leaf area $\left(4942.8 \mathrm{~cm}^{2}\right)$ which was statistically at par with $90 \mathrm{~kg} \mathrm{ha}^{-1}$, followed by $60 \mathrm{~kg} \mathrm{ha}^{-1}$ $\left(4752.1 \mathrm{~cm}^{2}\right)$, whereas less leaf area $(3769.5$ $\mathrm{cm}^{2}$ ) was obtained where potash was not applied. Among the hybrids, larger leaf area $\left(4797.3 \mathrm{~cm}^{2}\right)$ was recorded for CS200, followed by $3025\left(4677.9 \mathrm{~cm}^{2}\right)$ and $30 \mathrm{~K} 08$ $\left(4517.9 \mathrm{~cm}^{2}\right)$, while lower leaf area (4401.5 $\mathrm{cm}^{2}$ ) was recorded for 2031. Interaction between $\mathrm{K} \times \mathrm{H}$ showed that all the hybrids produced larger leaf area when $\mathrm{K}$ was applied at the rate of $90 \mathrm{~kg} \mathrm{ha}^{-1}$. Beyond 90 $\mathrm{kg} \mathrm{K} \mathrm{ha}^{-1}$ no further increase in leaf area was noted (Fig 1a).

\section{Plant height (cm)}

Potash $(\mathrm{K})$ application and hybrids $(\mathrm{H})$ as well as their interaction significantly affected plant height (Table 1). Long stature plants $(215.25 \mathrm{~cm})$ were produced when potash was applied @ $120 \mathrm{~kg} \mathrm{ha}^{-1}$ which was statistically comparable to $90 \mathrm{~kg} \mathrm{ha}^{-1}$, followed by $60 \mathrm{~kg} \mathrm{ha}^{-1}(198.37 \mathrm{~cm})$ whereas short stature plants $(179.43 \mathrm{~cm})$ were produced in control plots. In case of hybrids, 30K08 produced taller plants $(212.87 \mathrm{~cm})$, followed by CS200 $(205.87 \mathrm{~cm})$ and 3025 $(199.81 \mathrm{~cm})$ whereas short stature plants $(189.62 \mathrm{~cm})$ were recorded for 2031. As for as concerned with the interaction between $\mathrm{K}$ $\mathrm{x} \mathrm{H}$, mean data revealed that plant height increased significantly with the increase in potash level up to $90 \mathrm{~kg} \mathrm{ha}^{-1}$ in all hybrids. However no further improvement in plant height was recorded with application of $\mathrm{K}$ above $90 \mathrm{~kg} \mathrm{ha}^{-1}$ (Fig 1b).

\section{Number of plants at harvest $\left(\mathrm{ha}^{-1}\right)$}

Number of plants $\left(\mathrm{ha}^{-1}\right)$ at harvest was neither affected by potash (K) application nor by hybrids (Table 1). Interaction between $\mathrm{K}$ x $\mathrm{H}$ was also non-significant for number of plants at harvest. Number of ears plant $^{-1}$ was neither significantly affected by various potash $(\mathrm{K})$ levels nor by the hybrids (Table 1). 
Table-1: Plant height $(\mathrm{cm})$, leaf area plant $\mathrm{t}^{-1}\left(\mathrm{~cm}^{2}\right)$, ears plant $\mathrm{t}^{-1}$ and plants at harvest $\left(\mathrm{ha}^{-1}\right)$ of spring maize hybrids as affected by potash fertilization.

\begin{tabular}{|c|c|c|c|c|}
\hline Potash level & Leaf area plant ${ }^{-1}\left(\mathrm{~cm}^{2}\right)$ & Plant height $(\mathbf{c m})$ & Ears plant $^{-1}$ & Plants at harvest $\left(\mathrm{ha}^{-1}\right)$ \\
\hline 0 & $3759.5 \mathrm{c}$ & $179.4 \mathrm{c}$ & 2 & 54702 \\
\hline 60 & $4752.2 \mathrm{~b}$ & $198.3 \mathrm{~b}$ & 2 & 54642 \\
\hline 90 & $4940.3 \mathrm{a}$ & $215.1 \mathrm{a}$ & 2 & 51596 \\
\hline 120 & $4942.8 \mathrm{a}$ & $215.2 \mathrm{a}$ & 2 & 54583 \\
\hline LSD & 56 & 2.42 & Ns & Ns \\
\hline \multicolumn{5}{|l|}{ Hybrids } \\
\hline $30 \mathrm{~K} 08$ & $4518.0 \mathrm{c}$ & $212.8 \mathrm{a}$ & 2 & 51536 \\
\hline 2031 & $4401.6 \mathrm{~d}$ & $189.6 \mathrm{~d}$ & 2 & 54642 \\
\hline CS200 & $4797.3 \mathrm{a}$ & $205.8 \mathrm{~b}$ & 2 & 5458 \\
\hline 3025 & $4678.0 \mathrm{~b}$ & $199.8 \mathrm{c}$ & 2 & 54761 \\
\hline LSD & 56 & 2.42 & Ns & 25.36 \\
\hline Interaction & $* *$ & $* *$ & Ns & Ns \\
\hline
\end{tabular}

Means in similar category of columns with different alphabets differ significantly from each other at $\mathrm{p} \leq 0.05$ using LSD. $* *=$ Significant Ns $=$ Non significant

Table-2: Grains ear ${ }^{-1}, 1000$ grains weight $(\mathrm{g})$, grain yield $\left(\mathrm{kg} \mathrm{ha}^{-1}\right)$ and biological yield $\left(\mathrm{kg} \mathrm{ha}^{-1}\right)$ of spring maize hybrids as affected by potash fertilization.

\begin{tabular}{ccccc} 
Potash level & Grains ear & 1000 grains weight (g) & Grain yield $\left(\mathbf{k g ~ h a}^{-1}\right)$ & Biological yield $\left(\mathbf{k g ~ h a}^{-1}\right)$ \\
\hline 0 & $179.4 \mathrm{c}$ & $3759.5 \mathrm{c}$ & $3151 \mathrm{c}$ & $10496 \mathrm{c}$ \\
60 & $198.3 \mathrm{~b}$ & $4752.2 \mathrm{~b}$ & $3515 \mathrm{~b}$ & $11502 \mathrm{~b}$ \\
90 & $215.1 \mathrm{a}$ & $4940.3 \mathrm{a}$ & $4128 \mathrm{a}$ & $13580 \mathrm{a}$ \\
120 & $215.2 \mathrm{a}$ & $4942.8 \mathrm{a}$ & $4192 \mathrm{a}$ & $13462 \mathrm{a}$ \\
\hline LSD & 2.42 & 56 & 66 & 327 \\
\hline Hybrids & & & & $11516 \mathrm{c}$ \\
\hline 30 K08 & $212.8 \mathrm{a}$ & $4518.0 \mathrm{c}$ & $3547 \mathrm{c}$ & $11118 \mathrm{~d}$ \\
2031 & $189.6 \mathrm{~d}$ & $4401.6 \mathrm{~d}$ & $3424 \mathrm{~d}$ & $13630 \mathrm{a}$ \\
CS200 & $205.8 \mathrm{~b}$ & $4797.3 \mathrm{a}$ & $4143 \mathrm{a}$ & $12776 \mathrm{~b}$ \\
3025 & $199.8 \mathrm{c}$ & $4678.0 \mathrm{~b}$ & $3873 \mathrm{~b}$ & 327 \\
\hline LSD & 2.42 & 56 & 66 & $* *$ \\
\hline Interaction & Ns & $* *$ & $* *$ &
\end{tabular}

Means in similar category of columns with different alphabets differ significantly from each other at $\mathrm{p} \leq 0.05$ using LSD. $* *=$ Significant $\mathrm{ns}=$ Non significant 

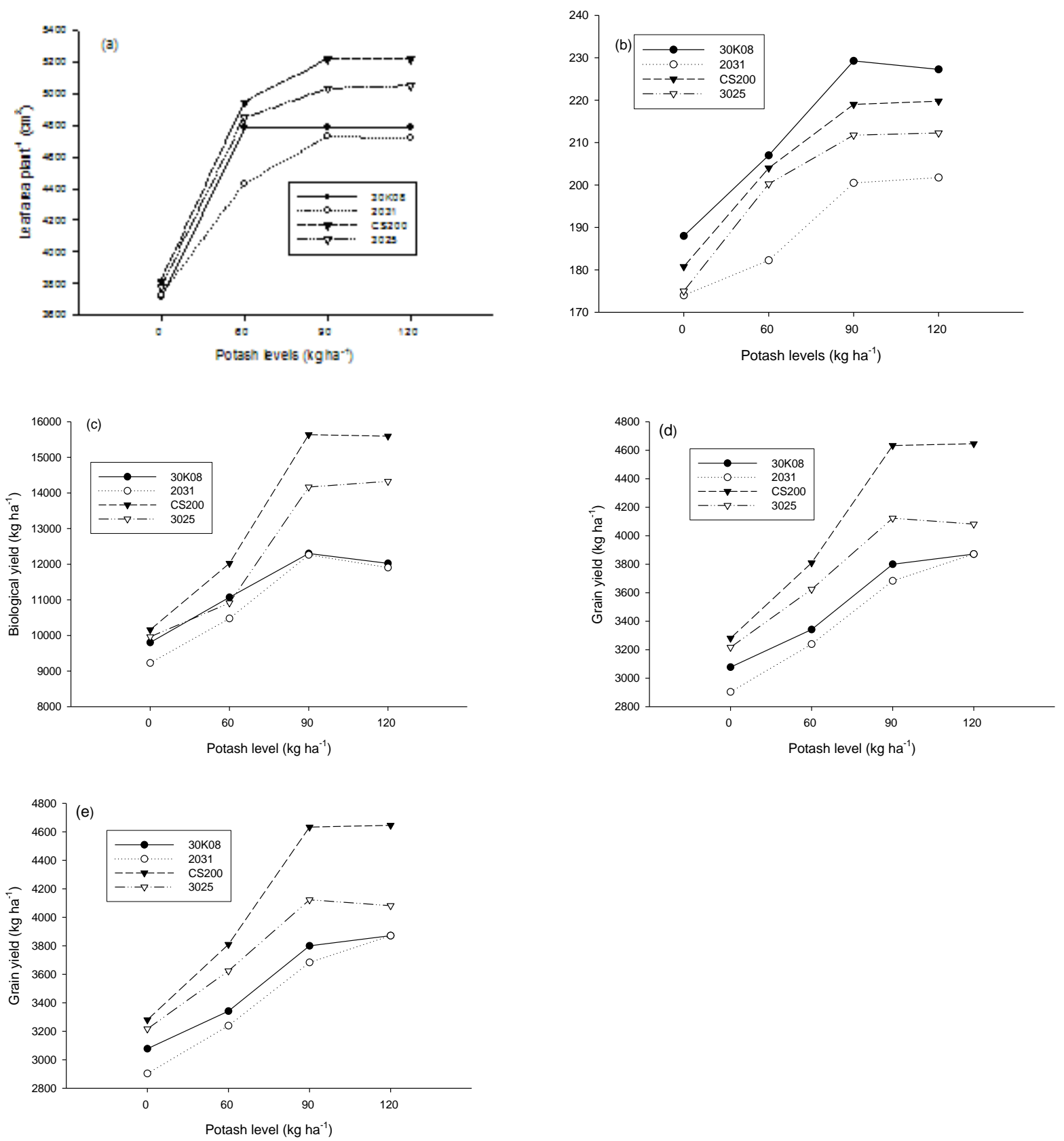

Figure-1. Interaction of potash and hybrids for (a) leaf area plant ${ }^{-1}$ (b) plant height (c) thousand grains weight (d) biological yield and (e) grain yield. 


\section{Number of ears plant ${ }^{-1}$}

Similarly equal number of ears plant ${ }^{-1}$ were also recorded between the interaction of $\mathrm{K} \mathrm{x}$ $\mathrm{H}$. Statistical analysis of the data revealed that potash $(\mathrm{K})$ application and hybrids $(\mathrm{H})$ had significantly affected grains ear ${ }^{-1}$ (Table 2). Interaction between $\mathrm{K} \times \mathrm{H}$ showed no significant difference for grains ear ${ }^{-1}$.

Number of grains ear ${ }^{-1}$

Application of potash at the level of $120 \mathrm{~kg}$ $\mathrm{ha}^{-1}$ resulted in more number of grains ear ${ }^{1}(547)$ however it was at par statistically with $90 \mathrm{~kg} \mathrm{~K} \mathrm{ha}^{-1}$, followed by $60 \mathrm{~kg} \mathrm{~K} \mathrm{ha}^{-1}$ (515), while lower grains ear ${ }^{-1}$ (484) were recorded for the plots where potash was not applied. Among the hybrids, CS200 produced higher number of grains ear ${ }^{-1}$ (539), followed by 3025 (531) then by 30K08 (519), while 2031 resulted in lower number of grains ear ${ }^{-1}$ (504).

\section{Thousand grains weight (g)}

Thousand grains weight was significantly affected by potash (K) application and hybrids $(\mathrm{H})$ as well as their interaction $(\mathrm{K} \mathrm{x}$ $\mathrm{H}$ ) was also significant (Table 2). Application of potash @ of $120 \mathrm{~kg} \mathrm{~h}^{-1}$ produced heavier thousand grains weight $(414.87 \mathrm{~g})$, followed by $90 \mathrm{~kg} \mathrm{ha}^{-1}(391.68 \mathrm{~g})$ then by $60 \mathrm{~kg} \mathrm{ha}^{-1}(378.12 \mathrm{~g}$ ), while control plots resulted in lighter thousand grains weight (354. $12 \mathrm{~g}$ ). In case of hybrids, CS200 produced heavier thousand grains weight $(395.18 \mathrm{~g})$, followed by 3025 (384.87 g) whereas 2031 produced lighter thousand grains weight $(375.37 \mathrm{~g})$. As for as concerned with the interaction between $\mathrm{K} \mathrm{x}$ $\mathrm{H}$, mean data revealed that thousand grains weight increased significantly with increase in potash level in all hybrids (Fig 1c).

\section{Grain yield ( $\left.\mathrm{kg} \mathrm{ha}^{-1}\right)$}

Data in Table 2 regarding grain yield shows that potash levels and hybrids significantly affected grain yield. Grain yield was also significantly affected by interaction between $\mathrm{K} \times \mathrm{H}$. Higher grain yield was recorded in those plots which received $120 \mathrm{~kg} \mathrm{~K}$ ha
${ }^{1}\left(4192 \mathrm{~kg} \mathrm{~h}^{-1}\right) 90 \mathrm{~kg} \mathrm{~K} \mathrm{ha}^{-1}\left(4128 \mathrm{~kg} \mathrm{~h}^{-1}\right)$ however both were statistically at par. Lower grain yield (3151 $\mathrm{kg} \mathrm{ha}^{-1}$ ) was obtained in control plots. Among the hybrids, higher grain yield $\left(4143 \mathrm{~kg} \mathrm{ha}^{-1}\right)$ was produced by CS200, followed by 3025 $\left(3873 \mathrm{~kg} \mathrm{ha}^{-1}\right)$ and $30 \mathrm{~K} 08\left(3547 \mathrm{~kg} \mathrm{ha}^{-1}\right)$, whereas lower grain yield $\left(3424 \mathrm{~kg} \mathrm{ha}^{-1}\right)$ was produced by 2031. In case of interaction hybrid-CS200 sharply increased grain yield as $\mathrm{K}$ level was increased up to $90 \mathrm{~kg} \mathrm{~K} \mathrm{ha}^{-1}$. Hybrid-3025 increased grain yield linearly as $\mathrm{K}$ level increased up to $90 \mathrm{~kg} \mathrm{~K} \mathrm{ha}^{-1}$. Beyond $90 \mathrm{~kg} \mathrm{~K} h a^{-1}$ no further increase in grain yield was observed (Fig 1e).

\section{Biological yield $\left(\mathrm{kg} \mathrm{ha}^{-1}\right)$}

Data in association with biological yield revealed that there was significant variation for potash $(\mathrm{K})$ application and hybrids $(\mathrm{H})$ (Table 2). Data collected on this plant parameter also revealed that interaction between $\mathrm{K} \times \mathrm{H}$ had significant. Application of potash@90 kg ha-1 resulted in higher biological yield (13580 $\left.\mathrm{kg} \mathrm{ha}^{-1}\right)$ however it was statistically at par with $120 \mathrm{~kg} \mathrm{~K} \mathrm{ha}^{-1}$, followed by $60 \mathrm{~kg} \mathrm{~K} \mathrm{ha}^{-1}\left(11502 \mathrm{~kg} \mathrm{ha}^{-1}\right)$, while plots where potash was not applied resulted in lower biological yield $(10496 \mathrm{~kg}$ $\mathrm{ha}^{-1}$ ). Among the hybrids, CS200 produced higher biological yield (13630 $\left.\mathrm{kg} \mathrm{ha}^{-1}\right)$, followed by $3025\left(12776 \mathrm{~kg} \mathrm{ha}^{-1}\right)$ and 30K08 (11516 kg ha-1), whereas 2031 produced lower biological yield $(11118 \mathrm{~kg}$ $\left.\mathrm{ha}^{-1}\right)$. As for as concerned with the interaction between $\mathrm{K} \times \mathrm{H}$, biological yield tended to increase up to $90 \mathrm{~kg} \mathrm{~K}^{\mathrm{ha}}{ }^{-1}$ in all hybrids, however further increase did not significantly affected biological yield in all hybrids (Fig 1d).

\section{Discussion}

Growth parameters like leaf area and plant height are mainly controlled by the genotypic makeup and it can also be affected by the soil and environmental factors. For photosynthesis, leaf area is the most important plant factor to produce 
photosynthetic product. Stature of the plant differ crops in a number of ways and had a positive effect on the biological yield. Growth parameters (leaf area and plant height) were significantly improved with potash level $90 \mathrm{~kg} \mathrm{ha}^{-1}$. Improvement in growth parameters with potash application might be due to delayed leaf senescence, sustained leaf photosynthesis and better vegetative growth. Our results are also confirmed by [10-12]. Taller plants were observed for the hybrids 30K08 and CS200. Short stature plants were recorded for the hybrids 3025 and 2031. Hybrid-CS200 and hybrid -3025 produced larger leaf area as compared to hybrid-30K08 and hybrid2031, respectively. Variation among the hybrids in growth parameters might be due to their genetic superiority. Interaction of $\mathrm{K}$ $\mathrm{x} \mathrm{H}$ also significantly altered the growth parameters. Growth parameters were linearly improved with the application of potash at the rate of $90 \mathrm{~kg} \mathrm{ha}^{-1}$ in all hybrids. Findings of our study are in line with $[3,13$ 16] who also found improvement in growth parameters in different cultivars with the application of potash. Grain yield is seen in terms of increased grain yield due to increased number of grains ear ${ }^{-1}$, heavier thousand grains weight and increase in number of ears plant ${ }^{-1}$. Yield parameters are the vital parameters and are end product of any management strategies. Yield components of maize (number of grains ear ${ }^{-1}$ and thousand grains weight) responded positively to potash fertilization and hybrids. Number of grains ear ${ }^{-1}$ was significantly increased when potash was applied @ $90 \mathrm{~kg}$ $\mathrm{ha}^{-1}$, whereas heavier thousand grains weight was obtained when potash was applied at the level of $120 \mathrm{~kg} \mathrm{ha}^{-1}$. Increase in yield components with potash fertilization might be due to potassium has important role in water use efficiency, improved plant growth condition and cell division and also results in quick transportation toward grain as reported by [17]. Hybrids also varied for yield components. Among the hybrids, CS200 was the best hybrid in terms of higher number of grains ear $^{-1}$ and heavier thousand grains weight in comparison with the rest of the hybrids. Maize hybrids varied in the number of grain ear $^{-1}$ and thousand grains weight, possibly due to difference in genetic potential of hybrids. Interaction of $\mathrm{K}$ $\mathrm{x} \mathrm{H}$ had also significant effect on thousand grains weight. In all hybrids heavier thousand grains weight was obtained with the application of potash at the rate of 120 $\mathrm{kg} \mathrm{ha}^{-1}$. Similar trends were also reported by $[17,18]$.

Grain yield and biological yield were significantly affected by potash fertilization, hybrids as well as their interaction $(\mathrm{K} \times \mathrm{H})$. Grain yield and biological yield increased significantly by applying potash at the amount of $90 \mathrm{~kg} \mathrm{ha}^{-1}$. Reason behind the increase in grain yield and biological yield might be increase in potash level increased the rate of $\mathrm{CO}_{2}$ assimilation, stabilized the osmosis regulation, improved stomata closure and enzyme activity as a result of which more carbohydrates might have produced which might have increased grain yield and biological yield as observed by [19]. Hybrids also differed in grain yield and biological yield. Hybrid-CS200 out yielded in terms of grain and biological yield. It may be due to the fact that hybrids responded differently for grain and biological yield due to their different genetic potential expressed in terms of difference in leaf area, plant height, grain number ear $^{-1}, 1000$ grain weight, and prolificacy. Application of potash at the rate of $90 \mathrm{~kg} \mathrm{ha}^{-1}$ improved grain and biological yield of all hybrids. Findings of our study are in line with [2, 10].

\section{Conclusion}

It was concluded that application of potash @ $90 \mathrm{~kg} \mathrm{ha}^{-1}$ improved number of grains ear $^{-1}$, thousand grains weight and grain 
yield. Protein content with increasing level of potash as compared to control plots. Among the hybrids CS200 performed well by producing more number of grains ear ${ }^{-1}$, heavier thousand grains weight and higher grain yield. Hence it is recommended that hybrid-CS200 with application of potash at the rate of $90 \mathrm{~kg} \mathrm{ha}^{-1}$ for obtaining higher grain yield.

\section{Acknowledgements}

We are thankful to the Department of Agronomy, The University of Agriculture, Peshawar, KPK, Pakistan for providing all the necessary facilities for conducting the research.

\section{References}

1. Bukhsh MA, Ahmad R, Iqbal J, Maqbool MM, Ali A, Ishaque M \& Hussain S (2012). Nutritional and physiological significance of potassium application in maize hybrid crop production. Pakistan J. Nutri. 11:187202.

2. Mengel K \& Kirkby EA (1987). Principles of Plant Nutrition, 4th Edn., International Potash Institute, Horgen, Switzerland.

3. Bukhsh M, Ahmad R, Iqbal J, Rehman A, Hussain S \& Ishaque M (2011). Potassium application reduces bareness in different maize hybrids under crowding stress conditions. Pakistan J. Agri. Sci. 48:31-37.

4. Bukhsh MA, Ahmad R, Ishaque M \& Malik A (2009). Response of maize hybrids to varying potassium application in Pakistan. Pakistan J. Agri. Sci. 46:179-184.

5. Bukhsh MA (2010). Production potential of three maize hybrids as influenced by varying plant density and potassium application. Ph.D. dissertation, Department of Agronomy, University of Agriculture, Faisalabad.
6. Nawaz I (2006). Genetic differences for the potassium nutrition of different maize cultivar. Proc. Int. Conference. Strategies for Crop Improvement against Abiotic Stresses.Department of Botany, University of Agriculture, Faisalabad, Pakistan.

7. Minjian C, Haiqui Y, Hongkui Y \& Chungi (2007). Difference in tolerance to potassium deficiency between maize inbred lines. Plant Prod. Sci.10:42-46.

8. Epstein E \& Bloom A (2005). Mineral nutrition of plants: Principles and Perspectives, 2. Sinauer Associates, Sunderland. MA.

9. Steel RGD \& Torrei JH (1980). Principles and procedure of statistics. McGraw-Hill. New York. USA.

10. Baligar VC, Fageria NK \& He Z L (2001). Nutrient use efficiency in plants. Comm. Soil Plant Analysis. 32: 921-950.

11. Tahir M, Tanveer A, Ali A, Ashraf M \& Wasaya A (2008). Growth and yield response of two wheat (Triticum aestivum L.) varieties to different potassium levels. Pak. J. Life Soc. Sci. 6(2): 92-95.

12. Laghari, GM, Oad FC, Tunio S, Gandahi AW, Siddique MH, Jagirani AW \& Oad SM (2010). Growth, yield and nutrient uptake of various wheat cultivars under different fertilizer regimes. Sarhad J. Agric. 26(4): 491497.

13. Wakeel A, Aziz T \& Hassan A (2005). Growth and potassium uptake of maize (Zea mays L.) in three soils differing in clay contents. Emirates J. Agric. Sci. 17(1): 57-66.

14. Hussian F, Malik AU, Haji MA \& Malghani AL (2011). Growth and yield response of two cultivars of mungbean (Vigna radiata L.) to different 
potassium levels. J. Anim. and Plant Sci. 21(3): 622-625.

15. Yang X E, Wang WM \& He ZL (2004). Physiological and genetic characteristics of nutrient efficiency of plants in acid soils.P.78-83.

16. Aslam M, Zamir MSI, Afzal I \& Yaseen M (2004). Morphological and physiological response of maize hybrids to potassium application under drought stress. J. Agric. Res. 51(4): 443-454.

17. Marschner H (1995). Mineral nutrition of higher plants. Academic Press, Sandiego, Ca, pp: 379-396.
18. Akhtar M, Ahmad S, Mohsin S \& Mehmood T (1999). Interactive effect of Phosphorous and Potassium nutrition on the growth and yield of hybrid maize. Pak. J. Bio. Sci. 2:240-241.

19. Tabatabaii S, Ebrahimi YM, Khorshidi MB, Benam \& Tabrizi EFM (2011). Effect of potassium fertilizer on corn yield (Jet acv.) under drought stress condition. American- Eur. J Agri and EnviScie. $10(2)$ 257-263. 